Gianantonio, C. A., et al. (1968). Fournal of Pediatrics, 72, 757. Gianantonio, C. A., et al. (1973). Nephron, 11, 174.

Gilchrist, G. S., et al. (1969). Lancet, 1, 1123.

Gower, J. C. (1966). Biometrika, 53, 325.

Gower, J. C. (1968). Biometrika, 55, 582.

Gower, J. C., and Ross, G. J. S. (1969). Applied Statistics, 18, 54.

Gower, J. C., and Ross, G. J. S. (1969). Applied Statistics, 18,

Hardisty, R. M., and Ingram, G. I. C. (1965). Bleeding Disorders, Oxford, Blackwell Scientific.

Kaplan, B. S., et al. (1971). Fournal of Pediatrics, 78, 420.

Katz, J., et al. (1971), fournal of Pediatrics, 78, 426

Katz, J., et al. (1973). Fournal of Pediatrics, 83, 739

Lieberman, E. (1972). Fournal of Pediatrics, 80, 1.

Merskey, C., Kleiner, G. J., and Johnson, A. J. (1966). Blood, 28, 1.

Metz, J. (1972). British fournal of Haematology, 23, Suppl., p. 53.

Moncrieff, M. W., and Glasgow, E. F. (1970). British Medical fournal, 3, 188.

Monnens, L. (1974). Personal communication.
Monnens, L., et al. (1972). Acta Helvetica Paediatrica, 27, 45.

Poliwoda, H., et al. (1969). New England fournal of Medicine, 280, 689.

Prentice, C. R. M., and McNicol, G. P. (1973). In Recent Advances in Thrombosis, ed. L. Poller, p. 151. London, Churchill.

Ratnoff, O. D., and Menzie, C. (1951). Fournal of Laboratory and Clinical Medicine, 37, 316.

Sanchez Avalos, J., et al. (1970). Fournal of Pediatrics, 76, 538

Sharp, A. A., and Eggleton, M. J. (1963). Fournal of Clinical Pathology, 16, 551 .

Sherry, S. (1973). Thrombosis et Diathesis Haemorrhagica, 29, 3.

Shinton, N. K., et al. (1964). Archives of Disease in Childhood, 39, 455.

Tune, B. M., Leavitt, T. J., and Gribble, T. J. (1973). Fournal of Pediatrics, 82, 304.

Vitacco, M., Sanchez Avalos, J., and Gianantonio, C. A. (1973). Fournal of Pediatrics, 83, 271 . Willoughby, M. L. N., et al. (1972). Archives of Disease in Childhood, 47,

Winterborn, M. H., White, R. H. R., and Stuart, J. (1972). Lancet, 1, 1071.

\title{
New Japanese Rubella Vaccine: Comparative Trials
}

\author{
JENNIFER M. BEST, J. E. BANATVALA, JENNIFER M. BOWEN
}

British Medical fournal, 1974, 3, 221-224

\section{Summary}

A total of 142 seronegative volunteers were given one of the following rubella vaccines: Cendehill, HPV77. DE-5, RA27/3, or a new Japanese vaccine, To-336. To-336 vaccine produced a slightly higher geometric mean antibody titre (G.M.T.) (65.7) than did the HPV77. DE-5 $(63.1)$ or RA27/3 vaccine (61.9) but the G.M.T. induced by Cendehill vaccine was much lower (39-3).

Reactions, particularly joint symptoms, occurred least commonly after vaccination with To-336 vaccine. Joint symptoms occurred within seven days of menstruation in 30 out of $37(81 \%)$ vaccines $(P<0.01)$; their incidence was not related to oral contraception.

Though there is evidence to suggest that Japanese virus strains may be non-teratogenic further data on the incidence of congenitally acquired infection in Japan must be collected before this conclusion can be supported on epidemiological grounds.

\section{Introduction}

Vaccination with attenuated rubella virus now makes congenitally acquired rubella a potentially preventable disease, and in the U.K. it is official policy to offer vaccination to 11-14-year-old schoolgirls (Department of Health and Social Security, 1970). Though routine rubella vaccination of women of child-bearing age is not advised it is recommended for women at special risk of acquiring rubella-for example, nurses and schoolteachers (Department of Health and Social Security, 1972). Because the teratogenicity of the current attenuated vaccines is unknown, however, vaccinees must not become pregnant for at least two months after vaccination (Department of Health and Social Security. 1970). Despite this warning many terminations have been carried out because of inadvertant vaccination during pregnancy (Center for Disease Control, 1973; Registrar General, 1973). Furthermore, analysis of U.S. data shows that the im-

\footnotetext{
Department of Virology, St. Thomas's Hospital and Medical School, London SE1 7EH

JENNIFER M. BEST, B.SC., PH.D., Lecturer

J. E. BANATVALA, M.D., M.R.C.PATH., Reader
}

mune status of $86 \%$ of 208 pregnancies terminated for this reason had not been established before vaccination (Center for Disease Control, 1973). Thus vaccines composed of strains that are not transmitted to the fetus, provided that they are still immunogenic, would constitute a major advance in the development of rubella vaccines.

Some Japanese workers claim that though the pattern of postnatally acquired rubella in Japan is similar to that in most western countries congenitally acquired disease is rare, and they have attributed this to the fact that Japanese strains are of reduced teratogenicity (Kono et al., 1969). In vitro studies have shown that when compared with U.S.-derived strains with a similar passage history Japanese strains induce significantly higher levels of interferon in primary human placental cell cultures but not in fetal lung cultures or leucocyte preparations (Banatvala et al., 1971 ; Potter et al., 1973). One of these Japanese strains, To-336, has been attenuated by passage in primary guinea-pig kidney cell cultures and undergone preliminary trials in Japan ( $R$ Kono, personal communication). Though encouraging these trials are difficult to evaluate, for the To-336 vaccine was not tested in parallel with established vaccines. We have therefore compared this new vaccine with RA27/3, Cendehill, and HPV77. DE-5 vaccines, the last of which, though extensively used in the U.S.A. and other parts of the world, is not yet licensed in the U.K.

\section{Subjects and Methods}

Sera from 578 nurses, 78 student physiotherapists, and 20 laboratory technicians at St. Thomas's Hospital aged between 17 and 32 years were screened for rubella antibodies by haemagglutination inhibition (H.A.I.) tests (Feldman, 1968; Cooper et al., 1969). Altogether $150(22 \cdot 2 \%)$ were seronegative, 142 of whom participated in the trial. After signing a consent form each subject was allocated at random to one of four groups, each of which was allocated one of the following vaccines: Cendehill (Huygelen and Peetermans, 1967), HPV77. DE-5 (Buynak et al., 1968), RA27/3 (Plotkin et al., 1965), and To-336. All vaccines were given subcutaneously and the subjects were bled about eight weeks after vaccination. Sera taken before and after vaccination were tested in parallel by H.A.I. using four units of antigen.

Virus Excretion.-Whenever possible swabs were taken from 12 to 17 subjects in each group on alternate days between the 8 th and 29th days after vaccination. Pharyngeal and nasal swabs taken un each occasion were immersed in the same bottle of 4 $\mathrm{ml}$ of virus transport medium. Specimens were inoculated into 
Vero cell cultures, after which virus was identified by cytopathic effect in RK13 cell cultures. Specimens were declared negative if no virus was detected after two passages in RK13. All specimens containing rubella virus were titrated in Vero cell cultures, the virus being identified again by a single passage in RK13.

Vaccine Reactions.-After vaccination the subjects recorded their symptoms daily for 30 days on a self-evaluation chart. All those with rash or joint symptoms were asked to report immediately the symptoms developed in order to be examined clinically. Details of whether vaccinees were taking oral contraceptives, as well as the date of onset of their two previous menstrual cycles, were also obtained. In addition a group of 39 nurses due to be screened later for rubella antibodies completed self-evaluation charts in order to provide a control group for assessing the reactogenicity of the vaccines.

\section{Results}

\section{SEROLOGY}

Of the 142 vaccinees $136(95.8 \%)$ had developed antibodies eight weeks after vaccination. To-336 vaccine produced a slightly geometric mean titre (G.M.T.) (65.7) than did the HPV77. DE-5 (63.1) or RA27/3 (61.9) vaccines; the G.M.T. produced by Cendehill vaccine was much lower (39.3) (table I).

Of the six vaccinees who failed to develop H.A.I. antibodies two out of four who had received HPV77. DE-5 vaccine showed evidence of seroconversion by a radioimmunodiffusion technique, details of which will be reported later.

\section{VIRUS EXCRETION}

Rubella virus was isolated on at least one occasion from $63.6 \%$ of the vaccinees tested (table II). Though the majority of rubella virus isolations had titres of $\leqslant 10^{0.5} \mathrm{TCD}_{50} / 0.1 \mathrm{ml}, 11(20 \%)$ of the 55 samples titrated had titres $\geqslant 10^{1.5} \mathrm{TCD}_{50} / 0 \cdot 1 \mathrm{ml}$. Virus was most often isolated between days 8 and 14 with To-336, RA27/3, and Cendehill vaccines but with HPV77. DE-5 vaccine virus was most often isolated between days 15 and 21 (table III).

\section{REACTIONS}

Joint symptoms occurred frequently with the HPV77. DE-5 $(38.7 \%)$ and $\operatorname{RA27} / 3(41.7 \%)$ vaccines, less often with Cendehill vaccine $(22.9 \%)$ and were least common with To-336 $(17.6 \%)$ vaccine (table IV). These differences however, were not statistically significant $(P>0.05)$. Multiple joint involvement and arthritis-that is, joint swelling or limitation of movement or both-were more often encountered with the HPV77. DE-5 vaccine (table V). Nevertheless, the incidence of arthritis with this vaccine did not differ significantly from that induced by the RA27/3 or To-336 vaccine $(P>0.05)$, but the Cendehill vaccine caused a significantly lower incidence of arthritis than did the HPV77. DE-5 vaccine $(P<0.01)$. The knees, fingers, metacarpophalangeal joints, and wrists were most commonly involved (table VI). Onset of joint symptoms generally occurred between the 13th and 21 st days after vaccination (mean 15 days), but three vaccinees, each of whom had received a different vaccine experienced characteristic symptoms within five days of vaccination. No arthralgia was experienced by the controls.

TABLE I-H.A.I. Antibody Titres Eight Weeks After Vaccination

\begin{tabular}{|c|c|c|c|c|c|}
\hline Reciprocal of H.A.I. Titre & Cendehill & HPV77.DE-5 & RA27/3 & To-336 & Total Vaccinees \\
\hline $\begin{array}{r}<4 \\
4 \\
8 \\
16 \\
32 \\
64 \\
128 \\
256 \\
512 \\
\end{array}$ & $\begin{array}{r}1 \\
3 \\
5 \\
15 \\
6 \\
3 \\
2 \\
1 \\
\end{array}$ & $\begin{array}{r}4^{*} \\
\\
2 \\
7 \\
13 \\
7 \\
2\end{array}$ & $\begin{array}{r}1 \\
9 \\
17 \\
8 \\
1\end{array}$ & $\begin{array}{r}1 \\
\\
4 \\
2 \\
19 \\
6 \\
3\end{array}$ & $\begin{array}{r}6 \\
3 \\
12 \\
33 \\
55 \\
24 \\
8 \\
1\end{array}$ \\
\hline Total vaccinees & 36 & 35 & 36 & 35 & 142 \\
\hline $\begin{array}{l}\text { \%Conversion } \\
\text { Range } \\
\text { Median } \\
\text { G.M.T. }\end{array}$ & $\begin{array}{c}<4 \frac{97 \cdot 2}{512} \\
32 \\
39 \cdot 3\end{array}$ & $\begin{array}{c}<4 \frac{88 \cdot 6}{64} 256 \\
63 \cdot 1\end{array}$ & $\begin{array}{c}16-256 \\
64 \\
61.9\end{array}$ & $\begin{array}{c}<4 \frac{97 \cdot 1}{64} 256 \\
64 \cdot 7\end{array}$ & $\begin{array}{c}95 \cdot 8 \\
<4 \frac{64}{64} 512 \\
56 \cdot 1\end{array}$ \\
\hline
\end{tabular}

*Two of these vaccinees showed evidence of seroconversion by radioimmunodiffusion

TABLE II-Details of Rubella Virus Excretion

\begin{tabular}{|c|c|c|c|c|c|c|c|c|}
\hline \multirow{3}{*}{ Vaccine } & \multirow{3}{*}{$\begin{array}{l}\text { Proportion of } \\
\text { Vaccinees } \\
\text { excreting } \\
\text { virus }\end{array}$} & \multicolumn{7}{|c|}{ No. of Swabs (Days after Vaccination) } \\
\hline & & \multicolumn{6}{|c|}{ Virus Titres $\left(\mathrm{TCD}^{30} / 0.1 \mathrm{ml}\right)$} & \multirow[b]{2}{*}{ Total } \\
\hline & & $<10^{0.5}$ & $10^{0.6}$ & $10^{1.0}$ & $10^{1.6}$ & $10^{2.0}$ & $10^{2.5}$ & \\
\hline $\begin{array}{l}\text { Cendehill } \\
\text { HPV77.DE-5 } \\
\text { RA27/3 } \\
\text { To-336 }\end{array}$ & $\begin{array}{l}9 / 13(69 \cdot 2 \%) \\
8 / 12(66.7 \%) \\
7 / 13(53 \cdot 8 \%) \\
11 / 17(64.7 \%)\end{array}$ & $\begin{array}{c}5(12-23) \\
11(12-23) \\
5(12-26) \\
7(8-20)\end{array}$ & $\begin{array}{r}8(11-16) \\
8(13-26) \\
9(11-22) \\
13(11-25)\end{array}$ & $1(14)$ & $\begin{array}{l}1(12) \\
1(19) \\
7(12-22)\end{array}$ & & $\begin{array}{l}1(9) \\
1(15)\end{array}$ & $\begin{array}{l}15(9-23) \\
21(12-26) \\
14 *(11-26) \\
28^{*}(8-25)\end{array}$ \\
\hline Total & $35 / 55(63.6 \%)$ & $28(8-26)$ & $38(11-26)$ & $1(14)$ & $9(12-22)$ & & $2(9,15)$ & $78 \quad(8-26)$ \\
\hline
\end{tabular}

*One specimen not titrated.

TABLE III-Proportion of Pharyngeal Swabs taken from Vaccinees between Days 8 and 29 after Vaccination from which Virus was recovered

\begin{tabular}{|c|c|c|c|c|c|}
\hline \multirow{2}{*}{\multicolumn{2}{|c|}{ Vaccine }} & \multicolumn{3}{|c|}{ Days } & \multirow[b]{2}{*}{ Total } \\
\hline & & $8-14$ & $15-21$ & $22-29$ & \\
\hline $\begin{array}{l}\text { Cendehill } \\
\text { HPV77.DE-5 } \\
\text { RA27/3 } \\
\text { To-336 }\end{array}$ & & $\begin{aligned} 12 / 33 & (36.4 \%) \\
7 / 26 & (26.9 \%) \\
9 / 28 & (32.1 \%) \\
19 / 44 & (43.2 \%)\end{aligned}$ & $\begin{aligned} 2 / 25 & (8 \%) \\
10 / 26 & (38.5 \%) \\
4 / 31 & (12.9 \%) \\
7 / 38 & (18.4 \%)\end{aligned}$ & $\begin{array}{ll}1 / 23 & (4 \cdot 3 \%) \\
4 / 26 & (15 \cdot 4 \%) \\
2 / 27 & (7.4 \%) \\
3 / 36 & (8.3 \%)\end{array}$ & $\begin{array}{l}15 / 81(18 \cdot 5 \%) \\
21 / 78(26.9 \%) \\
15 / 86(17.4 \%) \\
29 / 118(24.6 \%)\end{array}$ \\
\hline & Total & $47 / 131(35.9 \%)$ & $23 / 120(19 \cdot 2 \%)$ & $10 / 112(8.9 \%)$ & $80 / 363(22 \%)$ \\
\hline
\end{tabular}


TABLE IV-Reactions occurring after Vaccination in Seroconverted Vaccinees and Controls

\begin{tabular}{|c|c|c|c|c|c|}
\hline & Cendehill & HPV77.DE-5 & RA27/3 & To-336 & Controls \\
\hline No. of subjects & 35 & 31 & 36 & 34 & 39 \\
\hline $\begin{array}{l}\text { Rubelliform rash } \\
\text { Lymphadenopathy } \\
\text { Joint symptoms }\end{array}$ & $\begin{array}{r}3(8 \cdot 6 \%) \\
11(31 \cdot 4 \%) \\
8(22 \cdot 9 \%)\end{array}$ & $\begin{array}{l}1(3 \cdot 2 \%) \\
17(54.8 \%) \\
12(38 \cdot 7 \%)\end{array}$ & $\begin{array}{c}9(25 \%) \\
16(44 \cdot 4 \%) \\
15(41 \cdot 7 \%)\end{array}$ & $\begin{array}{c}0 \\
13(38 \cdot 2 \%) \\
6(17.6 \%)\end{array}$ & $\begin{array}{c}14(2.6 \%) \\
0\end{array}$ \\
\hline
\end{tabular}

TABLE V-Foint Symptoms experienced by Seroconverted Vaccinees

\begin{tabular}{|c|c|c|c|c|c|}
\hline & Cendehill & HPV77.DE-5 & $\mathrm{RA} 27 / 3$ & To-336 & Total \\
\hline No. seroconverted: & 35 & 31 & 36 & 34 & 136 \\
\hline Joint symptoms & $8(22 \cdot 9 \%)$ & $12(38 \cdot 7 \%)$ & $15(41 \cdot 7 \%)$ & $6(17 \cdot 6 \%)$ & $41(30 \cdot 1 \%)$ \\
\hline $\begin{array}{l}\text { Arthralgia only } \\
\text { Arthritis } \\
\text { Multiple joint involvement (three joints or more) } \\
\text { Symptoms lasting seven days or more [actual } \\
\text { No. of days] }\end{array}$ & $\begin{array}{l}7(20 \%) \\
1(2 \cdot 9 \%) \\
4(11 \cdot 4 \%) \\
0\end{array}$ & $\begin{array}{l}4(12 \cdot 9 \%) \\
8(25 \cdot 8 \%) \\
10(32 \cdot 3 \%) \\
1(3 \cdot 2 \%) \\
{[42 * 1}\end{array}$ & $\begin{array}{l}9(25 \%) \\
6(16 \cdot 7 \%) \\
8(22 \cdot 2 \%) \\
2(5 \cdot 6 \%) \\
\quad[8 ; 8]\end{array}$ & $\begin{array}{l}2(5 \cdot 9 \%) \\
4(11 \cdot 8 \%) \\
4(11 \cdot 8 \%) \\
2(5 \cdot 9 \%) \\
{[14 \dagger ; 21 \ddagger]}\end{array}$ & $\begin{array}{l}22(16 \cdot 2 \%) \\
19(14 \cdot 0 \%) \\
26(19 \cdot 1) \% \\
5(3 \cdot 7 \%)\end{array}$ \\
\hline
\end{tabular}

*Stiffness of knees and discomfort on climbing stairs.

†Multiple joint involvement for up to five days initially, followed by arthritis in right knee after interval of two months, which persisted for 14 days.

$\ddagger$ Pain in metacarpophalangeal joints followed by slight morning stiffness.

Joint symptoms persisted for up to eight days with the RA27/3 vaccine (two cases), 14 and 21 days in two subjects given To-366 vaccine, and as long as 42 days in one given HPV77. DE-5 vaccine (table V). Only one vaccinee (Cendehill), however, lost time from work (one day) because of joint symptoms.

Joint symptoms did not appear to be related to the taking of oral contraceptives (table VII) or to age, since they occurred in $35(30 \cdot 7 \%)$ of the subjects 114 aged $17-24$ years and in $6(27 \cdot 3 \%)$ of the 22 aged 25-32 years. There was, however, a statistically significant association between joint symptoms and the menstrual cycle, for joint symptoms occurred within seven days of the onset of menstruation in $30(81 \cdot 1 \%)$ out of 37 of the vaccinees $(P<0.01)$ (table VIII).

Rash occurred in $9(25 \%)$ of the 36 vaccinees given RA27/3 vaccine. The rashes were faint, macular, and usually fleeting; rash was less often encountered with the other vaccines (table IV). One 18-year-old nurse developed erythema, oedema, and itching at the site of inoculation within seven hours of vaccination with $\mathrm{RA} 27 / 3$ vaccine, which responded to treatment with oral chlorpheniramine.

The overall incidence of malaise, sore throat, and lymphadenopathy was similar in the control and vaccinated groups.

TABLE VI-Foints most often involved

\begin{tabular}{|c|c|c|c|c|c|c|}
\hline & & Cendehill & $\underset{\text { DE-5 }}{\text { HPV77. }}$ & RA27/3 & To-336 & $\begin{array}{c}\text { Total } \\
\text { Vaccinees }\end{array}$ \\
\hline 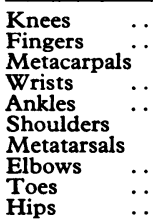 & $\begin{array}{l}\ldots \\
\cdots \\
\cdots \\
\cdots \\
\cdots \\
\cdots \\
\ldots\end{array}$ & $\begin{array}{l}4 \\
1 \\
2 \\
2 \\
2 \\
1 \\
2 \\
1 \\
1 \\
1\end{array}$ & $\begin{array}{r}11 \\
7 \\
5 \\
6 \\
2 \\
3 \\
1 \\
1 \\
0 \\
0\end{array}$ & $\begin{array}{r}6 \\
10 \\
4 \\
2 \\
1 \\
0 \\
0 \\
1 \\
0 \\
0\end{array}$ & $\begin{array}{l}3 \\
3 \\
4 \\
2 \\
2 \\
1 \\
0 \\
0 \\
0 \\
1\end{array}$ & $\begin{array}{r}24 \\
21 \\
15 \\
12 \\
7 \\
5 \\
3 \\
3 \\
1 \\
1\end{array}$ \\
\hline
\end{tabular}

TABLE VII-Relation between foint Symptoms and Oral Contraception (all Vaccines)

\begin{tabular}{|c|c|c|c|c|c|}
\hline & & & & $\begin{array}{l}\text { No. without } \\
\text { Joint Symptoms }\end{array}$ & $\begin{array}{l}\text { No. with } \\
\text { Joint Symptoms }\end{array}$ \\
\hline $\begin{array}{l}\text { On pill } \\
\text { Not on pill } \\
\text { No information }\end{array}$ & $\because$ & $\begin{array}{l}\cdots \\
\cdots\end{array}$ & $\begin{array}{l}. \\
\therefore\end{array}$ & $\begin{array}{r}23(69 \cdot 7 \%) \\
70(70.0 \%) \\
2(66.7 \%)\end{array}$ & $\begin{array}{c}10(30 \cdot 3 \%) \\
30(30 \%) \\
1(33.3 \%)\end{array}$ \\
\hline \multicolumn{4}{|c|}{ Total } & $95(69.9 \%)$ & $41(30.1 \%)$ \\
\hline
\end{tabular}
TABLE VII-Relation between Onset of Foint Symptoms and Menstrual Cycle
in 37 Vaccinees* (all Vaccinees)

\begin{tabular}{|c|c|c|c|}
\hline $\begin{array}{l}\text { Time of Onset of } \\
\text { Joint Symptoms }\end{array}$ & $\begin{array}{c}\text { No. }(\%) \text { of } \\
\text { Vaccinees } \\
\text { Within } \\
\text { Stated } \\
\text { Period }\end{array}$ & $\begin{array}{l}\text { No. (\%) of } \\
\text { Vaccinees } \\
\text { not Within } \\
\text { Stated } \\
\text { Period }\end{array}$ & Significance \\
\hline $\begin{array}{l}\text { Within } 7 \text { days before or after } \\
\text { onsset of cycle } \ldots \\
\text { Within } 5 \text { days before or after } \\
\text { onset of cycle } \\
\text { Within } 5 \text { days after onset of } \\
\text { cycle } \\
\text { Within } 5 \text { days before onset of } \\
\text { cycle.. }\end{array}$ & $\begin{array}{l}30(81 \cdot 1) \\
24(64 \cdot 9) \\
13(35 \cdot 1) \\
11(29 \cdot 7)\end{array}$ & $\begin{array}{l}7(18.9) \\
13(35 \cdot 1) \\
24(64 \cdot 9) \\
26(70 \cdot 3)\end{array}$ & $\begin{array}{c}\mathrm{P}<0.01 \\
\mathrm{P}<0.01 \\
0.01<\mathrm{P}<0.02 \\
0.05<\mathrm{P}<0.10\end{array}$ \\
\hline
\end{tabular}

*Details of menstrual cycle were available on 125 subjects, $37(29.6 \%)$ of whom had joint symptoms and $88(70.4 \%)$ had not. Of those with joint symptoms $9(24.3 \%)$
were vaccinated within five days of the onset of the cycle, and of those without joint
symptoms $35(39.8 \%)$ were vaccinated at that time. This difference is not significant wymptoms $35(39 \cdot 8 \%)$ were vaccinated at that time. This difference is not significant
$(0.2<\mathrm{P}<0.3)$.

\section{Discussion}

Our results show that the new Japanese vaccine, To-336, compares very favourably with currently available vaccines, for it produces a good level of serum antibody and is well tolerated in women. Comparable proportions of vaccinees excreted virus in each of the four groups. Numerous studies have shown that current vaccines, though excreted, are not transmitted to susceptible volunteers (International Conference on Rubella Immunization, 1969). Studies on susceptible children in closed communities in Japan have confirmed that the To-336 vaccine also shares this property (M. Uchibayashi, Takeda Chemical Industries, Osaka; personal communication). Though it is believed that lack of communicability may be related to the small amounts of virus being excreted a total of $11(20 \%)$ of the 55 rubella virus isolations yielded virus titres of $\geqslant 10^{1.5} \mathrm{TCD}_{50} /$ $0 \cdot 1 \mathrm{ml}$ (table II), this being comparable to virus titres detected in naturally acquired infections (Best and Banatvala, 1967). Perhaps attenuation results in some alteration of the biological properties of the virus whereby it replicates less favourably in the respiratory mucosa of susceptible contacts (Dudgeon et al., 1969).

HPV77. DE-5 vaccine has been used extensively in the U.S.A. as well as other parts of the world but clinical trials in adults in the U.K., though involving relatively small numbers, showed that this vaccine caused joint symptoms more often than did RA27/3 and Cendehill vaccines (Dudgeon et al., 1969). Our results, however, show a similar incidence of joint symptoms after vaccination with RA27/3 and HPV77. DE-5 vaccines, 
though HPV77. DE-5 vaccine produced rather more severe symptoms. Other workers have suggested that joint symptoms may be related to hormonal factors since they occur less often before puberty (International Conference on Rubella Immunization, 1969) and in those vaccinated post partum (Horstmann et al., 1970). Swartz et al. (1971) showed a significantly greater incidence of joint symptoms in those vaccinated within five days of the onset of menstruation than in those vaccinated six to 24 days after its onset. We were unable to confirm this finding (table VIII) but, in contrast, were able to show that joint symptoms are most likely to occur within seven days of the onset of menstruation. Since joint symptoms occurred most often 13 to 21 days after vaccination it should be possible to reduce their incidence significantly by vaccinating adult women in the last seven days of their cycle. Though Weibel et al. (1969) suggested that oral contraceptives protected against joint symptoms we were unable to confirm this, and our results are therefore in agreement with those of Monto et al. (1970) and Lerman et al. (1971).

We feel that our results are sufficiently encouraging to justify more extensive trials with the To-336 vaccine. This vaccine would, of course, have a considerable advantage if it were not transmitted to the fetus, but this could be determined only by examining the products of conception of seronegative women given To-336 vaccine who were due for therapeutic abortion for other reasons, or by examining the conceptuses of women inadvertently vaccinated with this vaccine during pregnancy. In our opinion the former method would raise considerable ethical problems and data could be accumulated only by the latter method if To-336 vaccine were used extensively over a prolonged period. Though Kono et al. (1969) showed that Japanese rubella viruses, including the To-336 strain, were not transmitted to rabbit fetuses whereas U.S.-derived strains were, we were unable to confirm these results (J. E. Potter and J. E. Banatvala, unpublished data).

At present an assessment of the teratogenicity of Japanese rubella virus strains in man can be made only indirectly by epidemiological methods, and one of us (J.E.B.) recently visited Japan to obtain as much information as possible at first hand.

Rubella was prevalent in many parts of Japan between 1965 and 1970; however, a questionnaire designed to assess the incidence of congentially acquired rubella during the five-year period, sent at the end of December 1970 to the paediatric, ophthalmic, and otolaryngology departments of 950 general hospitals throughout the country, resulted in only 47 cases being notified, most of which occurred in southern Japan (R. Kono, personal communication). This contrasts with data provided by the National Congenital Rubella Surveillance Programme in the U.K. Thus in the U.K., which has a population about half that of Japan, it is estimated that about 200 cases of congenitally acquired rubella occur during a non-epidemic year, though only about $25 \%$ are actually reported during that particular year (W. Marshall, personal communication). Nevertheless, differences in the incidence of congenital rubella may only reflect the efficiency of the two methods of survey, many cases in Japan, particularly in remote areas, remaining undiagnosed or if diagnosed not reported. About half of the Japanese hospitals approached, however, had virological facilities, and those that did not had access to them elsewhere.

A further explanation which might account for the apparent rarity of congenital rubella in Japan could be that most women of child-bearing age are already immune, particularly since Japanese women tend to marry and bear children at a rather later age than in many western countries. It has been shown, however, that during the child-bearing period of 19-29 years of age the proportion of seronegative women varies from $13 \%$ to $23 \%$ in the southern prefectures and from $9 \%$ to $14 \%$ in the northern ones (Committee of Rubella Epidemiological Study,
1971), confirming that the proportion of seronegative women of child-bearing age is indeed similar to that in most western countries.

It is also possible that Japanese women differ biologically in their response to rubella virus. The island of Okinawa, however, with a population of 933,800 , most of whom are Japanese, experienced an extensive rubella epidemic in 1965 which resulted in the birth of 352 rubella-affected babies (Hirayama, 1970). Kono et al. (1971) suggested that the high incidence of congenital deformities may have arisen from the importation of U.S.-derived rubella strains which spread from U.S. military bases to the indigenous population. Though Hirayama (1970) suggested that the proportion of rubella-susceptible women $(40 \%)$ was largely responsible for the large number of congenitally acquired infections and that the low incidence of congenital rubella on the mainland resulted from most adult women being already immune, this suggestion is not supported by the seroepidemiological studies quoted above.

Whether congenitally acquired rubella is really rare in Japan and if it is whether this is because Japanese rubella virus strains are not transmitted to the fetus cannot be determined at present. We, however, feel that data accumulated so far should encourage Japanese workers to develop a longitudinal surveillance programme on a national basis, all possible cases of congenitally acquired infection being referred centrally for both clinical and virological assessment as is the case in the U.K. and the U.S.A.

We are grateful to Miss J. Potter, Mrs. M. Rusby, and Miss B. Totterdell for technical help; to Merck Sharp and Dohme, the Wellcome Foundation, Smith Kline and French, and Takeda Chemical Industries for the supply of vaccines and general help; and to Dr. R. Kono, National Institute of Health, Tokyo, for his advice relating to Japanese epidemiological data.

We are also grateful for the co-operation given to us by the St. Thomas's Hospital School of Nursing and School of Physiotherapy, particularly Miss R. E. Johnston, sister in charge of the nurses clinic.

This study was supported by funds from the Wellcome Trust.

\section{References}

Banatvala, J. E., Potter, J. E., and Best, J. M. (1971). Fournal of General Virology, 13, 193.

Best, J. M., and Banatvala, J. E. (1967). Fournal of Hygiene, 65, 263

Buynak, E. B., et al. (1968). Fournal of the American Medical Association, $204,195$.

Centre for Disease Control (1973). Morbidity and Mortality, 22, No. 17. Committee of Rubella Epidemiological Study (1971). Preliminary Report. Tokyo, Ministry of Health. (In Japanese.)

Cooper, L. Z., et al. (1969). Fournal of the American Medical Association, $207,89$.

Department of Health and Social Sect

Departular 9/70. London, D.H.S.S. for Women of Childbearing Age, Circular 17/72. London, D.H.S.S.

Dudgeon, J. A., Marshall, W. C., and Peckman, C. S. (1969). American Fournal of Diseases of Children, 118, 237.

Feldman, H. A. (1968). Proceedings of the Society for Experimental Biology and Medicine, 127, 570 .

Hirayama, M. (1970). Paediatria Universitatis Tokyo, 18, 41.

Horstmann, D. M., Liebhaber, H., and Kohorn, E. I. (1970). Lancet, 2, 1003

Huygelen, C., and Peetermans, J. (1967). Archiv für die gesamte Virusforschung, 21, 357.

International Conference on Rubella Immunization (1969). American fournal of Diseases of Children, 118, No. 1 .

Kono, R., et al. (1969). Lancet, 1, 343.

Kono, R., et al. (1971). In Proceedings-International Conference on the Application of Vaccines against Viral, Rickettsial and Bacterial Diseases Application of Vaccines against Viral, Rickettsial and Bacterial Diseases
of Man, No. 226 p. 273. Washington, Pan|American Health Organization.

of Man, No. 226 p. 273. Washington, Pan!American Health Organization.
Lerman, S. J., et al. (1971). Annals of Internal Medicine, 74, 67.
Monto, A. S., Cavallaro, J. J., and Whale, E. H. (1970). Archives of Internal Medicine, 126, 6.35.

Plotkin, S. A., Cornfeld, D., and Ingalls, T. H. (1965). American fournal of Diseases of Children, 110, 381 .

Potter, J. E., Banatvala, J. E., and Best, J. M. (1973). British Medical fournal, 1, 197.

Registrar General (1973). Statistical Review of England and Wales for 1971, Supplement on Abortion, London, H.M.S.O

Swartz, T. A., et al. (1971). American Fournal of Epidemiology, 94, 246.

Weibel, R. E., et al. (1969). New England Fournal of Medicine, 280, 682. 